\title{
WHITMAN AND "THE INDIAN PROBLEM": THE TEXTS AND CONTEXTS OF "SONG OF THE REDWOOD-TREE"
}

\author{
Steven Blakemore and Jon Noble
}

WaLt WhitMAN's "SONG OF THE REDWOod-TREe" has received scant scholarly attention since its publication in 1874 . Critics have generally seen the death of the Redwood as a metaphoric analogue of Whitman's physical condition, since he suffered a stroke roughly nine months before he wrote the poem, leaving his left side paralyzed. In addition, Manifest Destiny, Darwinian evolution, and ecological themes predominate since Whitman uses California as the site where the giant redwoods willingly acquiesce to the loggers' axes so that the future American race may culminate on western shores. ${ }^{1}$ While all these contexts figure in Whitman's poem, there is another theme that Whitman approaches with "indirection" ("Redwood-Tree" 1. 2) and that underwrites the poem's fundamental significance: Whitman is, inter alia, comparing the redwoods in the archetypal California forest with the demise of the "red" race in America, and he is attempting to crystallize a mythic resolution of what was historically known as "the Indian problem." In order to clarify the central nexus between the trees and the Indians, the poem's underlying texts and contexts need to be established and elucidated.

California, in Whitman's poetry, has a national significance, existing in the far west of the American continent in a state that was still in the process of being settled. In "Facing West from California's Shores" (1867), Whitman imagines himself facing east from California, "the circle almost circled," then facing "home again" wondering where the human race started from and where it will end (11. 4, 9). In "A Promise to California" (1867), Whitman poetically pledges to travel west to California, since the American "States tend inland and toward the Western sea" (1. 5), suggesting that the American experiment will culminate there on western shores. Writing to Rudolph Schmidt, his correspondent in Denmark (March 4, 1874), Whitman noted that he had written "Song of the Redwood-Tree" in order "to idealize our great Pacific half of America, (the future better half)"-suggesting that the American "marriage" of continental halves would be consummated in California. The poem was published in Harper's New Monthly Magazine in the first issue 
of February 1874. In a letter to Ellen M. O'Connor (dated February 3, 1874), Whitman complains that the poem had been published "in the last Harpers" and that it had been "abused \& sneered at in the newspaper criticisms, a good deal, (from what I glean) —of course, that last makes me feel very bad." Although it is difficult to reconcile that Whitman's poem had been published and subsequently criticized before February $3 \mathrm{rd}$, he seems to anticipate that it would be misunderstood. In another letter to Rudolph Schmidt (July 28, 1874), Whitman notes that the poem "pleased" him "more fully" than "any of my pieces of late years. But it is generally thought wild \& cloudy here." Since the poem is "A California song," as Whitman announces in the first line, the California context is crucial in understanding the poem's significance.

Indians had, of course, first inhabited California. Then the Spanish, through the Franciscans, established missions starting in 1769 and, when Mexico became independent from Spain, in 1821, the government parceled out the mission properties to its political favorites. American settlers started arriving in 1841 and by 1846 settlers at Sonoma seized control and proclaimed an independent California republic. Following the end of the Mexican war in 1848, the territory was ceded to the United States. The discovery of gold in the same year resulted in an influx of people from other states and the displacement of the native Indian populations. In fact, the gold rush of ' 48 drastically disrupted all aspects of traditional Indian life, and the subsequent results were even worse-including the forced removal or destruction of entire tribesafter California became the 31 st state in 1850. The scene of Whitman's poem is in "Mendocino country" (1. 11), the California coastal county north of San Francisco, where redwoods are located.

Whitman had an abiding interest in Indians all his life. ${ }^{4}$ While he was growing up in his teens, Indians east of the Mississippi were removed to reservations in Oklahoma. When he was twenty, the infamous "Trail of Tears" occurred (1838 and 1839), and during the formative stages of Leaves of Grass, the ongoing battles and skirmishes between natives and whites captured the national imagination. In 1847 there was the Pueblo uprising, the Grattan engagement in 1854, and the Rains conflict in 1855. In 1862 the Sioux uprising in Minnesota was forcibly suppressed. In 1864 Colorado Regiment Troops killed over 150 Cheyenne and Arapaho Indians in the infamous Sand Creek Massacre in which Col. John M. Chivington justified the killing of women and children with his notorious "nits make lice" pronouncement. In 1865, Whitman had a brief tenure as a clerk in the Bureau of Indian affairs, a governmental agency within the Department of the Interior, where he had the opportunity of meeting and conversing with visiting delegations of Indians. In Leaves of the Grass, references to Indians occur throughout, including in sections of "Song of Myself" and "The Sleepers." 
Most of Whitman's native representations are positive, and he wrote specific, albeit minor, poems about Indians in "Red Jacket (from Aloft)," "Osceola," and "Yonnondio"-first published respectively in 1884, 1888 , and 1890 . He also published an admiring poem in 1876 ("From Far Dakota's Cañons"), shortly after the battle of Little Big Horn, praising Custer for continuing "yet the old, old legend of our race" (1. 9)being indomitable in defeat - but Whitman also admired Indians who died bravely, a cultural commonplace of the era. ${ }^{5}$ Whitman, for instance, was an admirer of Logan's speech, the speech by the Indian leader Tachnedorus, or John Logan, first appearing in Jefferson's Notes on the State of Virginia (1785) and celebrated as an example of stoic native eloquence. In his notes on oratory, he considers the rhetorical strategy of highlighting himself in the third person: "Why not discuss myself by name, Walt Whitman, in my speeches-aboriginal fashion?-as in the speech of Logan." Whitman's attitude towards the Indians was, however, like his countrymen's, ambivalent. He was admiring yet had the common prejudices of the era. Ideologically conflicted, his ambivalence is thematically encapsulated in the poem of the redwoods.

Redwoods are evergreen timber trees that are indigenous to the Pacific Coast, stretching from southwestern Oregon to Central California. In Whitman's day, the redwoods extended from Oregon to thirty miles south of San Francisco. They can exceed heights over 300 feet; in Whitman's poem, the Redwood is 200 feet (1. 21). As they age, the lower limbs fall away, leaving a clear, columnar trunk. As soon as white settlers took control of California, the logging of redwoods was frenetic, and the discovery of gold intensified the demand for the trees. ${ }^{7}$ Redwoods are, of course, ancient and stately and, from Whitman's perspective, powerfully stoic, like the stereotypical depictions of Indians in the nineteenth century. In addition, redwoods are "native," "ancient," and were associated with native Indians in the nineteenth century. ${ }^{8}$ For instance, the genus of redwood trees known as Sequoia commemorates the great Cherokee Indian Sequoyah (also spelled Sequoya or Sequoia, 1766-1843) who served with the U.S. Army in the Creek War (181314 ) and who created the Cherokee writing system. In the poem, Whitman mentions three specific areas where the Sequoia flourished: Shasta, the mountain peak in Siskiyou County, the Nevadas-Sierra Nevada, the mountain range in eastern California where the Giant Sequoia grows along western slopes — and Yosemite (11. 41-43). The Redwood's reddish bark and heartwood make it analogous to the Indians' "red skin," and there was a series of tribes denominated "Redwood Indians" that inhabited the northern coast of California, precisely the locus of Whitman's redwoods along "the northern coast" in Mendocino country, the coastal county north of San Francisco (1. 11). These Indians built their traditional homes and canoes from planks split from fallen 
redwoods and believed the redwoods were living beings. Because the Whilkut, the Yurok, Karok, Hupa, Chilula, Wiyot, and Tolowa Indians all inhabited the redwood forests in northwestern California; the Indians in that area were generally denominated "Redwoods" or "Redwood Indians" by the whites. ${ }^{9}$ When gold was discovered in 1850 along the Trinity River in northwestern California, in the heart of the redwood area, the Indians were attacked or displaced by militia units comprising unemployed miners and other homesteaders. Frequent battles and skirmishes ensued throughout the decade.

While Whitman was writing his poem, the Indian problem in California resonated in the newspapers and journals. Through the 1870s, California tribes took up the famous Ghost Dance. ${ }^{10}$ The most publicized California Indian war occurred right before Whitman wrote his poem, in the fall of 1873, when the Modocs, a tribe living in northern California, made national news. Pressured by whites to move out of their original area, the Modocs had signed a peace treaty in 1864, agreeing to move to a reservation in Oregon in which they had to live with their traditional enemies, the Klamaths. Having unsuccessfully tried this, the Modocs fled the reservation in 1865, and after returning briefly in 1869 the tribe fled again, in 1870, under the leadership of the Modoc chief "Captain Jack" Kientpoos. After United States troops subsequently tried to force the Modocs back to the reservation, the Modocs retreated to "The Stronghold" - a vast network of caves and caverns in difficult and dangerous terrain. In January 1873, the army attacked the stronghold unsuccessfully, losing thirty-five men, and, in April, after weeks of negotiations, an unarmed U.S. peace delegation headed by Major General Edward Richard Canby fell to a surprise attack by Captain Jack in which the general and others in the delegation were killed. After the army attacked the stronghold again, the Modocs fled and after a series of skirmishes and wild-goose chases, Captain Jack and his men were finally compelled to surrender on June 1, 1873.

Captain Jack was hanged with three others for the death of the peace commissioners, and two other Modocs had their sentences commuted to life imprisonment. The remainder of the tribe was removed to a reservation in Indian Territory. One thousand U.S. troops were engaged in the Modoc War which cost over $\$ 500,000$, the lives of eightythree soldiers and seventeen Indians, becoming the most expensive of all the Indian wars, perhaps more significant than later, more famous battles such as Custer's last stand at the Little Big Horn, the massacre at Wounded Knee, and the resistance of Geronimo and Cochise. ${ }^{11}$

Whitman wrote "Song of the Redwood-Tree" in the fall of 1873, several months after the Modoc War had concluded. There was widespread coverage in the press. Richard Dillon notes that "American newspapers for 1872-1873 are full of excellent material on the Modoc War . . . between December 2, 1872, and October 5, 1873, for example, The 
New York Times ran fifteen stories," and the San Francisco newspapers "contributed the largest body of information on the campaign." A New York Herald reporter rushed to the scene after the death of General Canby, and Harper's Weekly started a series of eight articles that ran from April 26 through the June 28 issues. ${ }^{12}$ All these sources and contexts were available to Whitman. In addition, at the time of Whitman's poem, a variety of writers and painters had expressed their concern over the destruction of the virgin trees, and there was a general sense that the Indians, as a people, were in demise. ${ }^{13}$ The opening paragraph of the Harper's Weekly article on the Modoc War (May 3, 1873) recurs to the widespread perception that the Indians were on the brink of disappearing like some exotic, precarious florescence of nature: "the aboriginal race which is swiftly fading around us, like vegetation of some extinct geological era, has formed the subject of the discussions of humane men and generous legislators." 14 The "Indian problem" was a still an intensely debated subject during the time that Whitman was writing his poem in the fall of 1873, and the removal of the redwoods allowed him to both envision and rationalize the removal of the red man from the most western territory of the United States. Indeed, Whitman's distance from California allowed him to formulate a mythical resolution to the Indian crisis that nevertheless embodies the conflicting ambiguities of his, and the nation's, historical problem.

Thus, in the poem's opening, he approaches the topic as both a "prophecy and indirection"- the latter signifying an "oblique course or means" in Noah Webster's 1847 Dictionary. ${ }^{15}$ Except for the conventional sentimental and romanticized treatment of the Indians' demise, popularized in poems and novels such as Cooper's Last of the Mohicans (1826), almost any representation that took a position on the Indians would be, ipso facto, controversial, and Whitman could not subscribe to either of the two extreme positions: extermination or repatriation. In the poem, consequently, Whitman obliquely evades the historical situation by suggesting that the trees, and hence the red Indians, choose to fade away or be sacrificed of their own accord - but not before being incorporated into the mystical American body politic. Thus, Whitman created a mythic resolution to the historical problem, and it was a solution that simultaneously embodies both Whitman's imperial impulses as well as his iconoclastic inclusiveness.

The poem begins with a chorus of dryads "or hamadryads" departing, "fading" in conjunction with a "murmuring, fateful giant voice" of "a mighty dying tree," the lone Redwood (11. 3-5). Drawn from Roman mythology, dryads and hamadryads were wood nymphs inhabiting certain trees, although the hamadryads were more vulnerable since their health and well-being depended on the trees they inhabited. In Ovid's Metamorphoses, they let out a piercing cry when the trees are cut and begin to bleed. Whitman, throughout the poem, purposefully elides any 
suggestion of the shedding of sap or "red" blood (in contrast to European blood), and the reference to the minor deities of Roman mythology, instead of the native Indian belief that the trees themselves had spirits, coheres with his strategy of "indirection." 16

Whitman returned again to the dryads and hamadryads in an entry titled "The Lesson of the Tree" in Specimen Days:

How strong, vital, enduring! how dumbly eloquent! What suggestion of imperturbability and being, as against the human trait of mere seeming. Then the qualities, almost emotional, palpably artistic, heroic, of a tree; so innocent and harmless, yet so savage. ... Science (or rather half-way science) scoffs at reminiscences of dryad and hamadryad, and of trees speaking. But, if they don't, they do as well as most speaking, writing, poetry, sermons - or rather they do a great deal better. I should say indeed that these old dryad-reminiscences are quite as true as any, and profounder than most reminiscences we get. ${ }^{17}$

The dryads and hamadryads appear earlier in the 1874 poem and, of course, the tree eloquently speaks. In addition, Whitman, we suggest, associates the strength and heroism of the tree with what were perceived to be characteristics of the Indian - an argument we develop throughout. The tree is both "innocent," like the sentimentalized Noble Indian of western fiction, and "savage" ("harmless, yet so savage"). "Savage," of course, is a cultural synonym for "Indian" in the nineteenth century and reflects an oxymoronic linkage expressing the paradox of the Indian's savage innocence, although, in the poem, Whitman avoids any suggestion of savageness, since he promotes a noble abdication by the redwood "Indians." The mythological reference, however, associates the redwoods in the poem with the discredited mythology of the Old World as a way of suggesting that the ancient Indians' spirits have also passed their time and are fleeing and fading at a specific historical moment in the early 1870 s.

The lone Redwood represents the anachronistic Indian race soonto-be displaced by the "superber" white race (1.139). Whitman had, in fact, already thought of Indians as trees. In "An Indian Bureau Reminiscence" (1884), he related his memories of an Indian delegation while he was employed at the Bureau in 1865:

[The Indians were] the most wonderful proofs of what Nature can produce, (the survival of the fittest, no doubt - all the frailer examples dropt, sorted out by death) - as if to show the earth and woods, the attrition of storms and elements, and the exigencies of life at first hand, can train and fashion men, indeed chiefs, in heroic massiveness, imperturbability, muscle, and the last and highest beauty consisting of strength-the full exploitation and fruitage of a human identity, not from the culmination-points of "culture" and artificial civilization, but tallying our race, as it were, with giant, vital, gnarl'd, enduring trees, or monoliths of separate hardiest rocks, and humanity holding its own with the best of the said trees or rocks, and outdoing them. ${ }^{18}$ 
The paragraph encapsulates the way that Whitman sees the Redwood in the poem. Immersed in the earth and woods and associated with "nature" in the forest including rocks ("Redwood-Tree" 11. 26-30), the Redwood is gigantic, strong, and stoic (imperturbable), and just as Whitman in his reminiscence associates the Indians with the giant trees, he seems to associate the redwoods (albeit their ultimate endurance is contextualized in their final absorption into the new American race) with the "tallying" of the human race, and, as we will see, with the "white" American "race." In addition, Whitman was interested in Darwin, so the reference to the "survival of the fittest" also figures in the poem where Whitman's covert and camouflaged Indians are, mutatis mutandis, "sorted out by death" and "outdone" by the "superber" race and ultimately "broad humanity" (11. 39, 104). In other words, Whitman's representation of the potentially elegiac trees is transformed into their celebratory, evolutionary demise. ${ }^{19}$

In "Red Jacket (from Aloft)," Whitman also uses the Indian-tree figuration, comparing the grand sachem of the Iroquois with "some old tree, or rock or cliff" (1. 5). In "Yonnonido" (1887), he envisions "swarms" of Indians - the "Race of the woods"-fading and disappearing, "flitting by like clouds of ghosts," like the camouflaged redwood spirits of 1874 (1l. 5, 6). In An Indian Bureau Reminiscence, his characterization of the "aboriginal Americans," in "their physique and physiognomy," as "very remote, very lofty" metaphorically accords with the solitary "lofty top" (1.21) of the Redwood in the poem..$^{20}$

The source of the Redwood's fading death is the anonymous metonymical agency - the "strong arms" of white loggers (1. 13). In the poem, Whitman suggests that the trees and Indians naturally die ("Our time, our term has come," 1. 32) by voluntarily abdicating their expiring time and place to the forthcoming white race, and while he alludes to the violence, for the red tree is being chopped down, he metaphorically displaces it - the axes becoming "sharp tongues" that rive the tree (1. 14). The violence is additionally deflected by the union of Nature and man-made music, the "crackling blows of axes" sounding musically as the Redwood simultaneously responds with a contrapuntal "death-chant," suggesting a paradoxical harmony as the loggers create the space for white civilization out of the removal of the red race. "The choppers," representatives of the builders of the new society and culture in California, cannot hear the tree's "death-chant," (11. 16, 15), so Whitman intimates that the white man is oblivious to the real meaning of the red tree's sacrifice, even though he himself can "hear" the death song and hence comprehends the real significance of its death (11. 12-15).

Consider the image: a lone Redwood bravely sings its death chant in the precarious moment of being cut down by white loggers. This is a 
representation that captured the American imagination where, in countless historical and fictional accounts, the Indian, good or bad, faces death stoically, even singing as he dies. Roy Harvey Pearce notes that Americans considered Native American eloquence "and the far-fabled death songs" core Indian characteristics. ${ }^{21}$ The solitary Redwood surrounded by white loggers with axes as it sings its "death-chant" (1.15) certainly evokes the mythic stuff of Indian bravery and death songs. The difference is that Whitman refigures the death song, which was typically a song of stoic lament, or more famously, a defiant taunt, into an affirmation of the usefulness of the red tree's death to the culture that will cut it down. There may be an unintended ironic reversal as a lone white man or woman surrounded by Indians with tomahawks or axes (the weapon of Cooper's bad Indians in The Last of the Mohicans) is reconfigured into the image of the red tree surrounded by the white death party.

The axe is, of course, for Whitman the instrument of the new civilization in America - "the mighty and friendly emblem of the power of my own race, the newest, largest race" ("Song of the Broad-Axe" 1. 183). In "O Pioneers" it is an instrument of progress, as the "elder races" halt and "droop" while the American pioneers fell the "primeval forests" and nature conforms to the new imperial impulse (11. 13-14, 25). "Song of the Broad-Axe" (first published in 1856) is a poem often coupled with "Song of the Redwood-Tree" where, among those things, Whitman implicitly contrasts "The brisk short crackle of the steel driven slantingly into the pine" - the constructive building of civilization-with the destructive blood killing of the Old World (11. 63, 166-168). Cecelia Tichi notes that the New-World axe signifies, for Whitman, "a fundamental symbol of life and creation" and cites the preparatory notes to "Broad-Axe" in which Whitman wished the broad axe would replace the bald eagle as the new national symbol. ${ }^{22}$ In addition, Whitman's comment, in the poem, that "All waits or goes by default till a strong being appears; / A strong being is the proof of the race and the ability of the universe" (11. 137-138), coheres with the Redwood that has waited centuries so that he and his red race can fulfill their "natural" historical destiny by serving and expediting the advancement of the new, white race.

Indeed, the tree itself, in its "death-chant," joins, "as if" with its "heirs, the deities of the West" (1. 46)-the advancing American pioneer race-in a chorus and counter-allusion to the Old-World axes of the European executioner "clothed in red," the victim's blood upon him "wet and sticky," and ghostly "scaffolds" in "Broad-Axe" (11. 166167, 169-170, 172). In "Redwood-Tree," instead of the "red from Europe's old dynastic slaughter-house," land of "wars and scaffolds everywhere," the redwoods ("These virgin lands") come naturally "from 
Nature's long and harmless throes" to be "peacefully builded" (11. 49, 50-51). "Virgin lands" allusively include proverbial "virgin forests" in a poem where no virgin blood will be spilt as the virgin birth (the "harmless throes") and preparation of a new American space mythically ensures an intact purity despite the historical removal of red trees and Indians. The denial of blood and the cutting of red bark and skin is a way of projecting New-World violence back into the Old World-the "red from Europe's old dynastic slaughter-house." Whitman, in effect, deflects the violent cutting of the Redwood into the metaphoric material of the new civilization and transforms what could be perceived as excruciating death "throes" into nature's culminating "harmless throes" of labor. The unnamed sap/blood is similar to "the blood wash'd entirely away from the axe" in "Broad-Axe" (1. 178). It is a paradox Whitman employs throughout the poem: the death of the red race naturally produces the birth of a new civilization. The tree's voluntary death results in an even greater nativity. The adjective "harmless" (1. 51) accords with Webster's definitions in the 1847 Dictionary: "1. Not hurtful or injurious; innocuous . . . 2. Unhurt; undamaged; uninjured . . . 3. Innocent; not guilty." The felling of the Indian tree is paradoxically not an act of violence; Nature's labor pains are natural, as the death of the red race helps birth a greater race in terms of "the new culminating man" (1. 53). This is why the choral middle part (11. 55-72) is a mystical evocation of the spiritual, national forces invoked by the tree "to build" (1. 64). The tree apostrophizes "average spiritual manhood," "womanhood divine," the "unseen moral essence of all the vast materials of America," the "hidden national will lying in your abysms," unconscious "past and present purposes," and "vital, universal, deathless germs" (seeds) - all the gestating national, spiritual forces that will materialize in the impending future, in California.

It is precisely after the red tree's italicized death chant ceases that Whitman focuses on the moment it is chopped down as the elided violence is now sublimated:

Thus on the northern coast,

In the echo of teamsters' calls and the clicking chains, and the music of choppers' axes,

The falling trunk and limbs, the crash, the muffled shriek, the groan,

Such words combined from the redwood-tree, as of voices ecstatic, ancient and rustling. ... (11. 73-77)

In the poem's one savage moment when axes are not metaphoric "sharp tongues" (1. 14) and the tree is falling to its death, Whitman transforms the personal tragedy- "the muffled shriek, the groan"-into a "loftier strain" (11. 75, 44), into a public triumph, as the loggers' calls blend in with the tree's death chant and the "ecstatic" chorus of the other wood 
spirits, "ancient and rustling." ${ }^{23}$ Whitman turns the personal violence of the red race's end into a noble and natural sacrifice as the ancient race makes room for the future American race. But the momentary violence, the death/labor throe, is unseen and unheard by the innocent, murderous loggers and the "swarming" race outside the confines of the precarious red space (1. 90). The Indian tragedy, in Whitman's representation, is invisible to the American nation precisely because it is not a tragedy in its larger significance.

Indeed, the implicit castration of the red phallus causally welcomes the fertile explosion of the "swarming" race as all the dryads and Indian forest spirits withdraw precisely at the moment the red tree dies- "yielding" to a future flashing (11. 77-83).$^{24}$ Their departure, their voluntary removal, is not only from California but from the generalized Northwest- "From the Cascade Range to the Wahsatch, or Idaho far or Utah" (1. 79). In other words, they move from the Cascade, the range of mountains in California, Oregon, Washington, and British Columbia, as well as from the Wasatch, the range in northern Utah and southeastern Idaho. They hence move suggestively westward across the Pacific Ocean back into the Old World, since they are "yielding" to the westering "deities of the modern" (1. 80). The material sacrifice of the Indian tree, of course, represents the physical sacrifice of the red race while its spirits depart, exorcised of their own volition. It is as if Whitman transforms the ending of Milton's Nativity Ode, where the ancient pagan deities and spirits move reluctantly towards their new home in hell, into a happier fading before the flashing of the future.

The flashing appears immediately at the beginning of Section 2, just after the tree has died and the spirits have faded away: "The flashing and golden pageant of California" prepares for the arrival of the swarming race (1. 84). The flashing is, of course, the gold rush of 1848 and the resultant arrival of the white race into California. The spiritual seeds (the "hidden national will lying" in the vaginal "abysms") and gestation of lines 55-63 correspond to "the rich ores forming beneath" (1. 88) that now ripen into a material paradise where the swarming race will busily create a new culture and California commerce will unite both the East and the West, the Old and the New Worlds, in a stanza crescendoing down into the "diggings of yellow gold" (11. 87-93), reflecting the beginning "flashing and golden pageant of California." Whitman has, by sleight of hand, resolved the contradictions of the Indian problem by incorporating the California gold rush-one of the central causes of Indians' removal, their fading fall-into the dialectic of historical progress in which one race voluntarily dies and makes room for another.

Throughout the poem the red tree and its implicit attendant spirits have announced that their time has culminated in the climactic histori- 
cal purpose of their existence-making room and way for the "superber race" so that they can be incorporated into the total, evolutionary race experience: "To be in" the new white race "absorb'd, assimilated" (1. 43). In one sense, this assimilation is Whitman's imperialist fantasy of a nationalistic appropriation of both the Indians and their land in the throes of Manifest Destiny. Whitman resolves the contradictions of the Indian crisis by linguistically appropriating them into the service of the new nation. Their trunks and bodies may litter the landscape, but it is all spiritual building material and service for a greater civilization. Whitman's mythic resolution is a superficially kinder, gentler, literary imperialism that actually encodes a more repressive nationalist "denial" since it subtly transforms the violent removal of the Indians into the voluntary euthanasia of the red race: all those red trees happily laying down their lives for the "empire new" (1. 51). The historical reality of forced removals and massacres is transmuted into a loftier "indirection." In the final section of the poem, however, Whitman insists that the material blossoming of Section 2 is only "the means, the implements, the standing-ground" of the promise of a deferred future in the climactic culmination of "our common kind, the race"- "far more, than all your gold" (11. 96-101). The "standing-ground" for the future race is significant since "standing," in this context, signifies "Remaining erect, not cut down" (Webster's 1847 Dictionary, \#7), so that ground out of which the future race metaphorically grows is the final culmination of the human race that will stand its ground and not be cut down in contradistinction to the red race. ${ }^{25}$

The poem concludes with "Clearing the ground for broad humanity, the true America" (11. 104) - a clearing, of course, was the removal of trees: "A place or tract of land cleared of wood for cultivation; $a$ common use of the word in America, as Webster noted in the 1847 Dictionary, so a "clearing" of the ground simultaneously signifies the removal of the red trees and red Indians. In other words, a removal not to some arboreous reservation with land set-aside for aboriginal trees or nativesbut a complete clearing, a literary ethnic clearing of the Indian problem. Whitman, in effect, rationalizes the disappearance of the Indian by transmuting the red problem into a voluntary sacrifice in which the old race "yields," "abdicates" so that it may serve, pledge, and dedicate itself to the new master race (11. 33, 40, 54, 72). Whitman's vanishing Indian is an ideological wooden Indian, the last of the Red trees, camouflaged and mystified, along with the covert linkage between the Indian removal and the ecological genocide of the redwoods.

All this, however, needs to be contextualized. We have read into the previous two paragraphs our own culture's presuppositions. This contemporary reading is controlled by its own historical moment, and while it flushes out the nationalistic spirits of Whitman's poem, it is only 
one part of the poem's total significance. For certainly there was a more vigorous and virulent paradigm accessible to Whitman, who could have envisioned resistant redwoods obstinately obstructing progress before being forcibly removed by progressive axes. In fact, the obstruction of "progress" by "savages" was a historical justification for their removal or destruction. ${ }^{26}$ The "genius of the modern, child of the real and ideal" that clears the ground for "broad humanity" at the poem's end (11. 103104 ) is also a prophetic clearing of the white race that will make room for the climactic, culminating human race. The poem, in this sense, is also a child of the real and ideal in which the contradictions of history are reconciled in the mythic thesis. More fundamentally, the fact that Whitman engages in his signature endeavor to absorb the Indian (and everything else) into the nation's manifest destiny belies the straw-man paradigm with which an alien "other" is demonized and excluded. Whitman sees the redwoods as noble and admirable and, while there are obvious ideological problems with that vision, it still accords with his endeavor throughout Leaves to incorporate the Indian into the American experience. ${ }^{27}$

More fundamentally, Whitman clearly links the fate of the redwoods with the "swarming" race that replaces it. ${ }^{28}$ If the poem's solitary Redwood singing its death chant represents or stands for the collective red race, then Whitman, the poem's solitary singer, can also represent the white race in those readings that identify him with the vulnerable tree. The Redwood, at the beginning, has "joys unreck'd" yet recognizes that his personal "time" and later the collective "Our time" has finally come to an end. The trees, nevertheless, have "fill'd [their] time" (11. 8, 28, 32, 34). Similarly, the red tree, miming the white narrator (1. 2), prophesies that the "superber race" will also "fill their time" (1.39) before they also are suggestively removed so that an even superber people replaces them in the evolutionary progression of the race. Thus, in the future the white man will also "fill his time, / To duly fall, to aid, unreck'd at last, to disappear, to serve"(11. 70-72) — just like the redwoods. The white race is in the same historical/mythical situation as the red race: the white race will also be supplanted by a superber race and will fill its time by fulfilling its historical race destiny to contribute to human progress by also yielding and serving before falling and disappearing. The Redwood itself welcomes the coming of the white man to the very place where it will die and bids him to "gigantic grow, here tower proportionate to Nature" (1. 67). The white man is metaphorically equated to the red tree and its predestined end. Since white axes make the red tree naturally "fall," there is a metaphoric equivalence in the future cutting down and falling of the American race. The destinies of both peoples are the same, albeit at different historical and mythical points, and this racial equivalence is startling in a poem about the co- 
vert demise of the red race in the nineteenth century.

Whitman hence envisions the racial divide being absorbed into the "common kind," the future human race, in which the "clearing ground for broad humanity" will constitute the assimilation and absorption of all the races of the past into "a grander future" (11. 98, 105). Thus, the historical transition from the red to the white race is the penultimate stage in the eventual climactic assimilation and culmination of all races"the true America." Whitman suggests that this will happen in California on the same western ground where the white race absorbs the red race, which in turn will be absorbed by an even greater human race, "broad humanity," so he returns to American metaphors of "a New World" where, "in the true America," the last frontier, the metaphoric trunks and limbs of earlier civilizations will be assimilated "To build a grander future" (11. 102-106). It is a mythic rationalization, but it is also a meditation on the progressive possibilities of history in which every peoples' national tragedy signifies a higher calling.

Whitman's purposeful "indirection" and conspicuous camouflaging of the Redwood-Indian linkage tally with the mythical resolution as well as with the reason why the trees and Indians are metaphorically rather than directly connected. We have suggested that Whitman could not subscribe to either of the two extreme positions associated with the Indian problem - extermination or repatriation of the Indian tribesand hence he created a national fiction of voluntary sacrifice and abnegation for a higher cause. There are, of course, other possibilities why Whitman did not directly crystallize the connection. The poem could be a kind of psychological screen that prevented Whitman himself from confronting the full implications of what he was saying, although we think it improbable that Whitman did not realize the poem was about Indians as much as about redwoods. More pertinently, there is the possibility that he was experimenting with a kind of metonymic association that spatially and temporally attached Indians and redwoods as two groups of native inhabitants that were disappearing together in the sweep of nineteenth-century American history-so that by evoking the redwoods he automatically evoked the Indians. While there may be thematic and psychological intertwinings of all the above, Whitman's mythical resolution embodies his ambivalence about the Indian problem via the moral and situational equivalence that also presupposes the cutting and felling of the white American "race." The direct identification of Indians with trees would have made explicit the corollary-the potentially violent demise of the white race, not falling "naturally" but facilitated by the advance of an even superber race that would expedite its obsolescence. While Whitman disguises the primary rending in the tree's providential falling, as if it comes to the end of its time "naturally," a direct correspondence would have contradicted the teleology of manifest destiny as well as Whitman's commitment to American 
exceptionalism - a thesis that compels and energizes so many of his poems. Given the psychological, political, and cultural pressures and the realities of Whitman's own time, he did not explicitly express what he indirectly declares. Whitman, nevertheless, encodes a startling equivalence constituting one of the most culturally radical equations in nineteenth-century American poetry.

In the end, Whitman's strategies of indirection and the resolution of the Indian problem are simultaneously a deflection and displacement as well as an affirmative prophecy that both races will share the same proportionate sacrifice. If he rationalizes the Indians' removal as a projected, joyful, even triumphant acceptance, he also imagines their white counterparts stoically and joyfully accepting the same fateful sacrifice (11. 69-72). Published in 1874, at a specific historical moment when the Indian tribes were still being removed or destroyed, the poem's ambiguities - its tensions and ambivalences - reflect the contradictions and ambiguities of Whitman's American culture. One hundred and thirty years later, Whitman's attempt to poetically resolve one of the central historical contradictions of the American experience by balancing the mythic removal of the red race with a momentarily deferred countercutting of the "American" race, the dialectic second half of his "prophecy and indirection" (1. 2), makes "Song of the Redwood-Tree" a significant evolutionary text in the debate over race and culture in the nineteenth century.

\section{Florida Atlantic University, Boca Raton}

\section{NOTES}

1 For these approaches to the poem, see Gay Wilson Allen, The Solitary Singer: $A$ Critical Biography of Walt Whitman (New York: New York University Press, 1955, rev. 1967), 457-458; Betsy Erkkila, Whitman the Political Poet (New York: Oxford University Press, 1989), 287-288; M. Wynn Thomas, The Lunar Light of Whitman's Poetry (Cambridge, Mass: Harvard University Press, 1987), 139-140; Cecelia Tichi, New World, New Earth: Environmental Reform in American Literature from the Puritans through Whitman (New Haven: Yale University Press, 1979), 244-249; James Perrin Warren, "Contexts for Reading 'Song of the Redwood-Tree,", Reading under the Sign of $\mathrm{Na}$ ture: New Essays in Ecocriticism, ed. John Tallmadge and Henry Harrington (Salt Lake City: University of Utah Press, 2000), 165-178; Richard Chase, Walt Whitman Reconsidered (New York: Sloane, 1955), 148; Roger Asselineau, The Evolution of Walt Whitman: The Creation of a Personality (Cambridge: Harvard University Press, 1960), 218; Edwin Fussell, Frontier: American Literature and the American West (Princeton, N.J.: Princeton University Press, 1965), 433-434. All citations from Whitman's poetry are from Leaves of Grass and Other Writings, ed. Michael Moon (W. W. Norton \& Company, 2002). Line numbers will appear parenthetically within the text.

2 M. Jimmie Killingsworth first suggested the Redwood-Indian linkage in his luminous essay, "The Voluptuous Earth and the Fall of the Redwood Tree: Whitman's Personifications of Nature," Whitman East $\mathcal{E}$ West: New Contexts for Reading Walt 
Whitman, ed. Ed Folsom (Iowa City: University of Iowa Press, 2002), 20. Killingsworth's essay was first brought to our attention while our essay was under review.

3 The Correspondence, ed. Edwin Haviland Miller (New York: New York University Press, 1961), 2:282, 272, 309-310.

4 See chapter three of Ed Folsom's Walt Whitman's Native Representations (Cambridge: Cambridge University Press, 1994), 55-98.

5 See Roy Harvey Pearce, Savagism and Civilization: A Study of the Indian and the American Mind (Berkeley: University of California Press, 1953; rpt. 1988), 93, 97,100. In "Osceola," the subject of the poem is the old Seminole warrior's stoic death. In "From Far Dakota's Cañons," Whitman brings "no dirge" for Custer, only "a glad triumphal sonnet" (1. 22)—a good characterization of "Redwood-Tree."

6 Walt Whitman, Notebooks and Unpublished Prose Manuscripts, ed. Edward F. Grier (New York: New York University Press, 1984), 6:2233.

7 Lynwood Carranco and John T. Labbe, Logging the Redwoods (Caldwell, Idaho: The Caxton Printers, LTD., 1996), 13-18. The California gold rush created a huge demand for sawmill products such as the planks for the miners' sluices, flumes, and wing dams. By 1860 Mendocino and Humboldt counties had the largest mills. John W. Caughey, California: A Remarkable State's Life History (Englewood Cliffs, N.J.: Prentice-Hall, 1970), 202. There was hence a nexus between the gold rush and the redwoods: "What the discovery of gold did for the developing of Northern California, the redwood trees did for the Mendocino Coast. When in 1851 E. C. Williams, Jeremy Ford, Henry Meiggs, and Captain David Lansing, all lumbermen from New England who had come to California in search of gold, saw the vast redwood forests meeting the sea at the mouth of Big River, the Mendocino Coast soon became the mecca for lumbering men all the way from Maine and Canada to Michigan and Wisconsin." Lynwood Carranco and Estle Beard, Genocide and Vendetta: The Round Valley Wars of Northern California (Norman: University of Oklahoma Press, 1981), 46. Gary Snyder notes, "Commercial West Coast logging started around the 1870s," precisely the time Whitman was writing his poem; see The Practice of the Wild (New York: North Point Press, 1990), 131.

8 In the Indian Bureau, Whitman saw many Indians- the best "specimens" were, like the surviving redwoods, "the old or elderly chiefs, and the wise men." Cited in Folsom, 93.

9 A.L. Kroeber, Handbook of the Indians of California (New York: Dover publications, Inc., 1925; reprint, 1976), 202. See also Walter Van Dyke's personal reminiscence of the gold rush and the Redwood Indians in the 1850s, "Early Days in Klamath," The Overland Monthly 17 (No. 104, August 1891), 174-181 (especially 179); William J. Wallace, "Hupa Narrative Tales," The fournal of American Folklore 61 (No. 242, October-December, 1948), 346, 348, 351; "The Role of Humor in the Hupa Indian Tribe," The fournal of American Folklore 66 (April-June 1953), 139, 140. In 1850 s and 1860s, there was tension between Indians and whites in Mendocino County and massacres of the former by the latter in what has been characterized as the "Mendocino War." See Robert F. Heizer and Allen F. Almquist, The Other California: Prejudice and Discrimination under Spain, Mexico, and the United States to 1920 (Berkeley: University of California Press, 1971), 28-32, 37, 38. The redwoods in the poem signify generic "red" Indians rather than specific Redwood Indians. 
10 Barry M. Pritzker, A Native American Encyclopedia: History, Culture, and Peoples (New York: Oxford University Press, 2000), 114, 132, 136, 138, 139, 143, 147, 152, $156,157$.

11 Keith A. Murray, The Modocs and Their War (Norman: University of Oklahoma Press, 1959); Richard Dillon, Burnt-Out Fires (Englewood Cliffs: Prentice-Hall, 1973); Arthur Quinn, Hell with the Fire Out: A History of the Modoc War (Boston: Faber and Faber, 1977). Whitman was an acquaintance of Joaquin Miller who had lived among the Modocs in the 1850s. Miller published his reminiscences and defense of the Modocs in context of the Indian War of 1872-1873 in Life Amongst the Modocs (London, 1873).

12 Dillon, Burnt-Out Fires, 354; New York Herald reporter, Murray, The Modocs and Their War, 146. Warren A. Beck and David A. Williams note that "The Modoc Wars . . . caught the attention of a large part of the world"; see California: A History of the Golden State (Garden City, NY: Doubleday \& Company, 1972), 234.

13 Cecelia Tichi, New World, New Earth, notes that "when Whitman wrote The Song of the Redwood-Tree, the public valuation of the American wilderness had never been higher, and politically as well as aesthetically the preservation of the wilds was being publicized as advantageous to the nation" (248). See also Roderick Nash, Wilderness and the American Mind (New Haven: Yale University Press, 1967), 96-121.

14 Harper's Weekly (May 3, 1873), 364. Whitman subsequently published "Bravo, Paris Exposition," in Harper's Weekly in 1889.

15 Whitman was an admirer of Noah Webster's American Dictionary of the English Language and was most familiar with the 1847 edition. For Whitman's use of the dictionary, see Folsom, 12-26. Citations from the 1847 edition will appear parenthetically within the text.

16 For the Pacific North-Coast Indian belief that the redwoods were living spirit beings, see P. S. Sparkman, A. L. Kroeber, Thomas Waterman, and Edward Sapir, "Notes on California Folk-Lore," Fournal of American Folklore 21 (January-March 1908), 39; Pliny Earle Goddard, "Wayside Shrines in Northwestern California," American Anthropologist 15 (1913), 702; Richard Keeling, "Contrast of Song Performance Style as the Function of Sex Role Polarity in the Hupa Brush Dance," Ethnomusicology 29 (1985), 186. As David Boyle notes, "Animism, or spiritism, pervaded every nook and cranny of Indian belief . . . . [T] he hills, the rocks, the streams, the trees, and every object in nature as well as those produced by art, possessed a spirit"; see "On the Paganism of the Civilised Iroquois of Ontario," fournal of the Anthropological Institute of Great Britain and Ireland 30 (1900), 263-273. In the poem, the redwoods, rocks, mountains, "and all the earth" have consciousness and identity (11. 29-30).

17 Walt Whitman, Prose Works 1892, ed. Floyd Stovall (New York: New York University Press, 1963-1964), 1:130. Whitman wrote the passage in 1876 when he was convalescing at Timber Creek.

$18 P W, 2: 577$. In an anonymous article titled "Real American Red Men" that he wrote for the Washington Evening Star (September 20, 1872), Whitman admiringly describes a delegation of Sioux chiefs that he had just seen in imagery corresponding to the massive trees that he also admired: "the powerful and massive forms, the gnarly and luxuriant amplitude of their limbs and chests ... [ $t$ ] he inherent and athletic royalty of the man of the woods and mountains ... these natural kings, in shapes that make the types and samples of our civilized manhood, in America and Europe, shriv- 
eled and puny in comparison"; see Martin G. Murray, "The Poet-Chief Greets The Sioux," Walt Whitman Quarterly Review 17 (Summer/Fall 1999), 25, 26.

19 For Whitman's interest in Darwin, see James T. F. Tanner's article and bibliography in Walt Whitman An Encyclopedia, ed. J. R. LeMaster and Donald D. Kummings (New York: Garland Publishing, Inc., 1998), 163. In "Contexts for Reading 'Song of the Redwood-Tree," James Perrin Warren documents Whitman's interest in Darwinian evolution through, among other people and sources, his association with Asa Gray, professor of botany at Harvard University and popularizer of Darwin's 1859 Origin of Species. Coincidentally, Gray's presidential address to the American Association for the Advancement of Science in the summer of 1872 dealt with "Sequoia and its History" and was soon printed in several journals of popular science. While there is no way to confirm whether or not Whitman read the printed address, it does anticipate themes, explicit and implicit, in the poem. Gray begins by referring to the disappearance of trees on the prairies and then turns his attention to the redwoods, noting that they live in isolation and wondering if they are "now coming upon the stage (or rather were they coming but for man's interference) to play a part in the future? Or, are they remnants, sole and scanty survivors of a race that has played a grander part in the past, but is now verging to extinction?" $\mathrm{He}$ concludes that the redwoods are not destined "to play a conspicuous part in the future" and that other trees, though not as strong, "wholly overpower the Sequoias in numbers," and that "force of numbers eventually wins." In "Redwood-Tree," Whitman focuses on the imminent extinction of the redwood trees and the role that they play in history, just before they are overwhelmed by the "swarming" white race (1.90)-numbers eventually win. Gray is especially pessimistic about the duration of the coast redwood, "the most important tree in California," since it is highly desired for lumber. He can only wish that through the "traditions of centuries," the redwood trees could "tell us something of the history of their race"-precisely what preoccupied nineteenth-century historians and anthropologists with regard to the vanishing oral culture of the Indians. In the poem, the Redwood refers to the "untold life of me" (1. 24), mining the ubiquitous observation that the Indians' history and story were disappearing; see Asa Gray, Sequoia and its History: an address (Salem, MA: Salem Press, 1872), 4-8.

$20 \mathrm{PW}, 2: 579$. For the cultural significance of Indians as ghosts in American representations, see Killingsworth, 20.

21 Pearce, 79; cf. 97, 178, 179.

22 Tichi, 229, 238.

23 The "loftier strain" (1. 44) is a Virgilian echo of the opening of the famous fourth Eclogue and Virgil's invocation to the Sicilian Muses to sing a "loftier strain"-the standard English translation of paulo maiora in Whitman's time- "for orchard trees and humble tamarisks" (1-2). The fourth Eclogue prophesies the return of a new golden age, so the allusion corresponds with Whitman's prophecy of a new American era.

24 James E. Miller, Jr. sees the Redwood as a phallic symbol in the fecund earth (Walt Whitman [New York: Twayne, 1962], 131-132), but its felling additionally evokes castration.

25 Cf. $O E D$, second definition, "Of vegetation: that stands erect (in growth); growing (as distinguished from cut, felled, or laid low by a storm or the like)."

26 See Pearce, 41-42.

27 Cf. Folsom, 70, 72, 76, 94, 98. 
28 In "Yonnondio," the "muffled sonorous sound" (1. 11) preceding the Indians" disappearance is similar to "the muffled shriek" of the red tree just before its disappearance (1. 75). More pertinently, like the "swarming" white race in "Redwood-Tree," Whitman sees "swarms of stalwart chieftains, medicine-men, and / warriors," but at the end both the red and white races fade ("the cities, farms, factories fade") - and then all are "Blank and gone and still, and utterly lost" (11. 5, 11-12). The lament for the Indian's disappearing swarming race is simultaneously linked with the fading of white American civilization. 